\title{
ChemComm
}

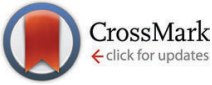

Cite this: Chem. Commun., 2015, 51, 10107

Received 30th April 2015, Accepted 14th May 2015

DOI: $10.1039 / \mathrm{c5cc03625a}$

www.rsc.org/chemcomm

\section{pH switchable anion transport by an oxothiosquaramide $\dagger$}

\author{
Robert B. P. Elmes,$\ddagger \S^{a}$ Nathalie Busschaert $\neq \boldsymbol{q}^{\mathrm{b}}$ Dawid D. Czech, ${ }^{\mathrm{b}}$ Philip A. Gale ${ }^{\star b}$ \\ and Katrina A. Jolliffe ${ }^{\star a}$
}

\begin{abstract}
An oxothiosquaramide was shown to bind to chloride through hydrogen bonding interactions in DMSO and found to exhibit $\mathrm{pH}$ switchable choride transport across phospholipid bilayers via an antiport transport mechanism.
\end{abstract}

The transport of anions across cellular membranes is an important biological function often mediated by specialised proteins embedded within cellular lipid bilayers. ${ }^{1,2}$ Intense effort is currently focussed on the development of small synthetic molecules that can mimic the role of such proteins. These have potential to treat diseases characterised by faulty anion transport ${ }^{3,4}$ or to induce cellular processes such as apoptosis. ${ }^{5,6}$ We have developed a number of simple hydrogen bonding receptors for anion transport containing urea, thiourea and squaramide groups. ${ }^{7-9}$ Transporters containing squaramides have proven particularly effective and mediate higher fluxes of anions than the analogous ureas or thioureas due to significantly higher anion affinities. ${ }^{9,10}$ More recently, we have shown that thiosquaramides display pH-dependent anion transport behaviour mimicking the gating/switching behaviour seen in biological systems. ${ }^{11}$ Thiosquaramides are significantly more acidic than their oxosquaramide analogues, and at $\mathrm{pH}>7$ are present as deprotonated species, unable to bind to or transport anions. Lowering the $\mathrm{pH}$ reprotonates the thiosquaramide and switches on anion transport, providing a

\footnotetext{
${ }^{a}$ School of Chemistry (F11), The University of Sydney, 2006 NSW, Australia. E-mail: kate.jolliffe@sydney.edu.au; Fax: +61 29351 3329; Tel: +61 293512297

${ }^{b}$ Chemistry, University of Southampton, Southampton, SO17 1BJ, UK.

E-mail: philip.gale@soton.ac.uk; Tel: +44 (0)23 80593332

$\dagger$ Electronic supplementary information (ESI) available: Synthesis and characterisation of the receptors, experimental details and figures relating to stability, association constant determination, stack plots and fitplots of the ${ }^{1} \mathrm{H}$ NMR titrations, $\mathrm{pH}$-spectrophotometric titrations, various vesicle assays methods and Hill plots. The data underlying this communication is available online at http://dx.doi.org/10.5258/SOTON/376697. See DOI: 10.1039/c5cc03625a

\$ These authors contributed equally to this work.

$\S$ Current address: Department of Chemistry, Maynooth University, National University of Ireland, Maynooth, Co. Kildare, Ireland.

T Current address: Department of Chemistry, Chemistry Research Laboratory, University of Oxford, 12 Mansfield Road, Oxford, OX1 3TA, UK.
}

potential method for targeting acidic environments in biological systems, without the need for external stimulation.

Given the significant differences in anion binding strength and $\mathrm{p} K_{\mathrm{a}}$ between oxo- and thiosquaramides, ${ }^{11-13}$ we were intrigued by the possibility that a mixed oxothiosquaramide derivative might exhibit intermediate behaviour between the two extremes, with 'switch-ON' anion transport behaviour occurring at a different $\mathrm{pH}$ to that observed for 2 , which could be more relevant to switching in biological systems. We therefore report here the synthesis, chloride binding and transport properties of the mixed oxothiosquaramide 3.

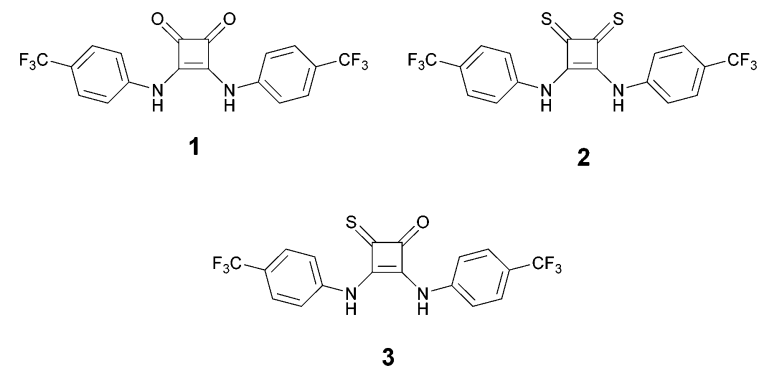

We previously found that conversion of oxosquaramide 1 to the thiosquaramide analogue 2 was most readily achieved using an excess of the crystalline $\mathrm{P}_{4} \mathrm{~S}_{10}$.pyridine thionating agent ${ }^{14}$ in MeCN. ${ }^{11}$ We reasoned that treatment of 1 with 1 equivalent of this reagent should yield a statistical mixture of compounds $1-3,{ }^{15}$ and found that this mixture was readily separable by flash chromatography to give 3 in $26 \%$ yield (see ESI $\dagger$ ).

Mixed oxothiosquaramides have not previously been investigated as anion binding motifs. In order to evaluate the chloride binding ability of $3,{ }^{1} \mathrm{H}$ NMR spectroscopic titrations at $298 \mathrm{~K}$ in $0.5 \% \mathrm{H}_{2} \mathrm{O}$ in DMSO- $d_{6}$ were performed by addition of tetrabutylammonium chloride (TBACl). The data $(\Delta \delta)$ was fitted to a $1: 1$ binding model using Hyperquad $\left.{ }^{(}\right)$(see ESI $\dagger$ for fitted data). ${ }^{16}$ The association constants $\left(K_{\mathrm{a}}\right)$ of $\mathbf{1 - 3}$ in $0.5 \% \mathrm{H}_{2} \mathrm{O}$ in DMSO- $d_{6}$ with $\mathrm{Cl}^{-}$are summarised in Table 1 . Both NH signals of 3 underwent significant downfield shifts (1.31 and $1.75 \mathrm{ppm}$ ) upon titration with chloride, indicating that both protons are involved in 
Table 1 Summary of the chloride association constants $K_{a}\left(M^{-1}\right)$ of receptors $1-3$ in $0.5 \% \mathrm{H}_{2} \mathrm{O}$ in DMSO- $d_{6}$ at $298 \mathrm{~K}^{a}$ and $\mathrm{p} K_{\mathrm{a}}$ values of receptors $1-3\left(6 \times 10^{-5} \mathrm{M}\right)$ measured by spectrophotometric titrations in acetonitrile/water $\left(9 / 1 \mathrm{v} / \mathrm{v}\right.$; in presence of $\left.0.1 \mathrm{M} \mathrm{TBAPF}_{6}\right)$

\begin{tabular}{lcc}
\hline Receptor & $K_{\mathrm{a}}\left(\mathrm{M}^{-1}\right)$ & $\mathrm{p} K_{\mathrm{a}}$ \\
\hline $\mathbf{1}$ & $458^{b}$ & $9.8^{b}$ \\
2 & $60^{b}$ & $5.3^{b}$ \\
3 & 470 & 6.6
\end{tabular}

${ }^{a}$ Data fitted to a 1:1 model with errors $<15 \%$. ${ }^{b}$ Value taken from ref. 11 .

hydrogen bonding. Compound 3 exhibited similar affinity for $\mathrm{Cl}^{-}$ to that of its squaramide counterpart 1, suggesting that incorporation of a single sulfur atom does not significantly alter the anion binding capacity of these compounds. This contrasts with the behaviour of thiosquaramide 2 , which binds only weakly to $\mathrm{Cl}^{-}$in this solvent.

To compare the acidity of the $\mathrm{NH}$ protons in compounds 1-3, $\mathrm{p} K_{\mathrm{a}}$ values were determined by $\mathrm{pH}$-spectrophotometric titrations in a mixture of acetonitrile/water $(9 / 1 \mathrm{v} / \mathrm{v}$; in the presence of $0.1 \mathrm{M} \mathrm{TBAPF}_{6}$ ) as described previously. ${ }^{11}$ Under these conditions, 3 was observed to undergo a single deprotonation event, characterised by a hypochromism at $\sim 372 \mathrm{~nm}$ and a concomitant hyperchromism at $\sim 396 \mathrm{~nm}$ (see Fig. 1). The titration profiles comparing 1-3 are shown in Fig. 1. The obtained $\mathrm{p} K_{\mathrm{a}}$ values corresponding to a single deprotonation event are summarised in Table 1. As expected, the mixed oxothiosquaramide 3 has a $\mathrm{p} K_{\mathrm{a}}$ intermediate between those of $\mathbf{1}$ and 2 . However, the $\mathrm{p} K_{\mathrm{a}}$ is much closer to that of the dithionated derivative 2 than
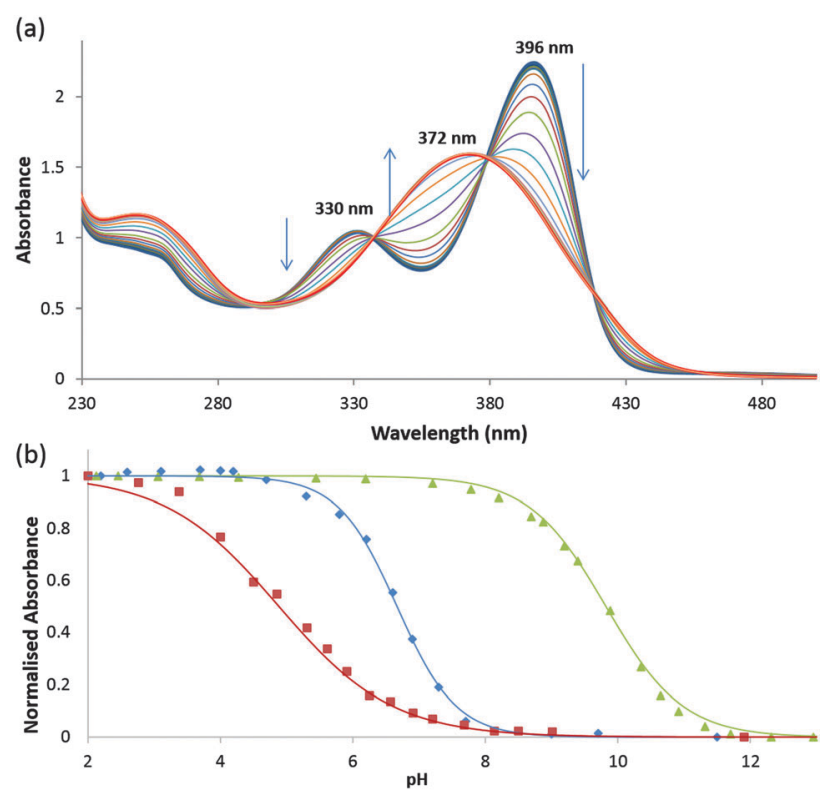

Fig. 1 (a) Absorption spectra taken over the course of a $\mathrm{pH}$-spectrophotometric titration of $3\left(6 \times 10^{-5} \mathrm{M}\right)$ in an acetonitrile-water mixture ( $9 / 1 \mathrm{v} / \mathrm{v}$; in presence of $0.1 \mathrm{M} \mathrm{TBAPF}_{6}$ ). (b) Comparison plots of normalised absorbance for $\mathbf{1}(\Delta), \mathbf{2}(\square)$ and $\mathbf{3}(\diamond) v s$. $\mathrm{pH}$. p $K_{\mathrm{a}}$ values were determined by fitting four parameter sigmoidal curves through the data points using Sigma Plot (Systat Software Inc., Chicago, IL, USA) with the point of inflexion corresponding to the $\mathrm{p} K_{\mathrm{a}}$. to that of 1 . Importantly, the $\mathrm{p} K_{\mathrm{a}}$ value of 6.6 suggests that 3 also exists in its deprotonated form at neutral $\mathrm{pH}$ and may therefore be useful as a pH-switchable anion transporter.

In order to evaluate the chloride transport properties of compound 3, previously reported vesicle-based procedures ${ }^{17}$ were employed under conditions allowing direct comparison to the reported chloride transport properties of $\mathbf{1}$ and 2.9,11 Unilamellar 1-palmitoyl-2-oleoyl-sn-glycero-3-phosphocholine (POPC) liposomes loaded with a $\mathrm{NaCl}$ solution (489 $\mathrm{mM}$ ) buffered to $\mathrm{pH} 7.2$ were prepared and suspended in an isotonic $\mathrm{NaNO}_{3}$ solution (489 mM) buffered to $\mathrm{pH}$ 7.2. A small volume of a DMSO solution of 3 was added to these liposomes and the resulting chloride efflux was monitored using an ion selective electrode (ISE). An analogous series of experiments were also performed at $\mathrm{pH}$ 4.0. The results for oxothiosquaramide 3 (Fig. 2) indicate that, like the thiosquaramide analogue 2, 3 possesses significantly enhanced anion transport ability at $\mathrm{pH} 4.0$, compared to that observed at $\mathrm{pH} 7.2$ (the results for the oxo-/thiosquaramides can be found in the ESI $\dagger$ ). This is consistent with the $\mathrm{p} K_{\mathrm{a}}$ value determined for 3 (6.6), which implies that at $\mathrm{pH} 7.2$ a significant proportion of this receptor will be deprotonated and thus negatively charged. Interestingly, the transport behaviour of 3 at low loading ( 0.1 mol\%) showed a more pronounced $\mathrm{pH}$ switching effect compared to higher loadings ( $1 \mathrm{~mol} \%$ ). This suggests that the 'trigger' to switch on anion transport may occur at a higher $\mathrm{pH}$ for 3 compared to that required for receptor 2 .

Hill analysis ${ }^{18}$ of the anion transport of 3 was performed at both $\mathrm{pH} 7.2$ and $\mathrm{pH}$ 4.0, and revealed that 3 is a poor anion transporter at $\mathrm{pH} 7.2$ but is an efficient anion transporter at pH 4.0 (Table 2). The mixed oxothiosquaramide derivative 3

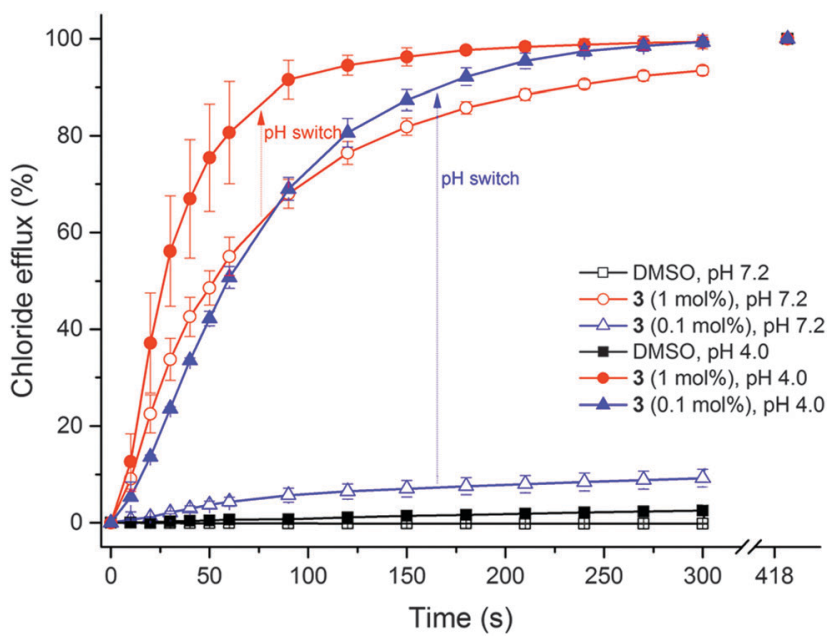

Fig. 2 Chloride efflux from POPC vesicles at pH 7.2 (empty symbols) and $\mathrm{pH} 4.0$ (filled symbols) mediated by oxothiosquaramide 3 ( $1 \mathrm{~mol} \%$ or $0.1 \mathrm{~mol} \%$ with respect to lipid). POPC vesicles were loaded with a $489 \mathrm{mM} \mathrm{NaCl}$ solution buffered to $\mathrm{pH} 7.2$ with $5 \mathrm{mM}$ phosphate salts or to $\mathrm{pH} 4.0$ with $5 \mathrm{mM}$ citrate salts, and were suspended in a $489 \mathrm{mM} \mathrm{NaNO}_{3}$ solution buffered to $\mathrm{pH} 7.2$ with $5 \mathrm{mM}$ phosphate salts or to $\mathrm{pH} 4.0$ with $5 \mathrm{mM}$ citrate salts. At the end of the experiment (300 s), detergent was added to lyse the vesicles and calibrate the ISE to $100 \%$ chloride efflux. Each point represents the average of a minimum of 6 independent trials. DMSO was used as a control. 
Table 2 Summary of the anion transport behaviour of receptor 1-3

\begin{tabular}{|c|c|c|c|c|}
\hline & $\begin{array}{l}\text { EC50 at pH } 7.2^{a} \\
(\mathrm{~mol} \%)\end{array}$ & $\begin{array}{l}\text { EC50 at } \\
\text { pH } 4.0^{a}(\mathrm{~mol} \%)\end{array}$ & $\begin{array}{l}\text { Retention } \\
\text { time }^{b} \text { (min) }\end{array}$ & $\begin{array}{l}\text { Apparent } \\
\mathrm{p} K_{\mathrm{a}}^{c}\end{array}$ \\
\hline 1 & $0.06^{d}$ & $0.08^{d}$ & 26.0 & $11.2( \pm 0.2)$ \\
\hline 2 & $0.68^{d}$ & $<0.0125^{d}$ & 26.6 & $6.0( \pm 0.2)$ \\
\hline 3 & 0.22 & 0.03 & 26.7 & $6.9( \pm 0.1)$ \\
\hline
\end{tabular}

${ }^{a}$ Concentration of transporter (mol\% with respect to lipid) needed to achieve $50 \%$ chloride efflux in $270 \mathrm{~s}$ from POPC vesicles filled with $\mathrm{NaCl}$ and buffered to $\mathrm{pH} 7.2$ or $\mathrm{pH} 4.0 .{ }^{b}$ Retention time of the compounds on a reversed-phase HPLC column. ${ }^{c} \mathrm{p} K_{\mathrm{a}}$ value obtained by performing anion transport studies at various $\mathrm{pH}$ (see main text for details). ${ }^{d}$ Value taken from ref. 11.

was found to exhibit chloride transport efficiencies intermediate between those of $\mathbf{1}$ and $\mathbf{2}$. At $\mathrm{pH}$ 7.2, transport activity was observed to follow the trend $\mathbf{1}>\mathbf{3}>\mathbf{2}$ which is consistent with the percentage of deprotonation as indicated by the trend in $\mathrm{p} K_{\mathrm{a}}$ values. A similar dependence of anion transport on the percentage of protonated receptor at physiological $\mathrm{pH}$ has also been observed for prodigiosenes. ${ }^{19} \mathrm{At} \mathrm{pH}$ 4.0, transport activity follows the general trend $\mathbf{2}>\mathbf{3}>\mathbf{1}$ and is consistent with a combination of lipophilicity (as determined by HPLC), which is an important factor in transport ability, and the expected anion binding ability of the receptors in their fully protonated forms. ${ }^{20-23}$

The chloride transport mediated by compound 3 may be either via the formation of membrane-spanning channels or via a mobile carrier mechanism. Oxo and thiosquaramides have previously been shown to function primarily via a mobile carrier mechanism ${ }^{9,11}$ and a series of vesicle-based experiments point towards 3 operating via a similar mechanism (see ESI $\dagger$ ). Calcein leakage assays ${ }^{24}$ revealed that the large highly anionic dye calcein does not leak from POPC vesicles at $\mathrm{pH} 7.2$ or pH 4.0 in the presence of 3 (see ESI $\dagger$ ), excluding the formation of pores or channels with large internal diameter and vesicle disruption induced by the transporters.

The charge imbalance created by transmembrane anion transport can be compensated by means of an antiport process or a symport process. The chloride efflux shown in Fig. 2 is therefore most likely the result of either a pure 'switch-on' $\mathrm{Cl}^{-} / \mathrm{NO}_{3}{ }^{-}$antiport mechanism or the occurrence of a $\mathrm{H}^{+} / \mathrm{Cl}^{-}$ symport process at lower $\mathrm{pH}$ (or a combination of both). To investigate which mechanism is dominant for receptor 3 , POPC liposomes containing a $\mathrm{NaCl}$ solution and suspended in a $\mathrm{Na}_{2} \mathrm{SO}_{4}$ solution were prepared at $\mathrm{pH} 7.2$ and $\mathrm{pH}$ 4.0. The double negatively charged sulfate anion is considerably more hydrophilic than nitrate $\left(\Delta G_{\mathrm{hydr}}\left(\mathrm{SO}_{4}{ }^{2-}\right)=-1080 \mathrm{~kJ} \mathrm{~mol}^{-1} ; \Delta G_{\mathrm{hydr}}\left(\mathrm{NO}_{3}{ }^{-}\right)=\right.$ $\left.-300 \mathrm{~kJ} \mathrm{~mol}^{-1}\right)^{25}$ and is therefore more challenging to transport across a lipid bilayer. It was found that under these conditions the efficiency of chloride transport was significantly reduced with a minimal amount of chloride being transported out of the liposomes at both pH 7.2 and pH 4.0 (see ESI $\dagger$ ). While these results strongly suggest that an antiport mechanism is the dominant process for the chloride transport facilitated by 3 , in principle $\mathrm{HCl}$ symport may account for some of the anion transport efficiency. A series of vesicle-based experiments were thus conducted using the $\mathrm{pH}$-dependent fluorescence properties of 8-hydroxy1,3,6-pyrenetrisulfonate (HPTS) in order to clarify this effect (see ESI $\dagger$ ). ${ }^{24}$ Initially, POPC liposomes were prepared containing $\mathrm{NaCl}(489 \mathrm{mM})$ and HPTS $(1 \mathrm{mM})$ buffered to $\mathrm{pH} 7.2$ or pH 6.0, and suspended in a $\mathrm{NaNO}_{3}(489 \mathrm{mM})$ solution buffered to $\mathrm{pH} 7.2$ or $\mathrm{pH} 6.0$. The results revealed that 3 is capable of effecting large changes in intravesicular $\mathrm{pH}$ even in the absence of a $\mathrm{pH}$ gradient (although to a lesser extent). The ability of $\mathbf{1}$ and 2 to change intravesicular $\mathrm{pH}$ was previously observed, however in the absence of a $\mathrm{pH}$ gradient the intravesicular $\mathrm{pH}$ did not change significantly upon the addition of these transporters (see $\mathrm{ESI} \dagger$ ). ${ }^{11}$ Taken together, these results indicate that the chloride effluxes shown in Fig. 2 are mainly the result of $\mathrm{Cl}^{-} / \mathrm{NO}_{3}{ }^{-}$ antiport processes but that $\mathrm{H}^{+} / \mathrm{Cl}^{-}$symport (or $\mathrm{OH}^{-} / \mathrm{Cl}^{-}$antiport) may also be an underlying mechanism. In conclusion, it appears that the chloride transport ability of receptor 3 is mainly the result of a $\mathrm{Cl}^{-} / \mathrm{NO}_{3}{ }^{-}$antiport mechanism that can be switched on by lowering the $\mathrm{pH}$, while $\mathrm{H}^{+} / \mathrm{Cl}^{-}$symport may also be contributing to the overall transport ability of 3 .

To probe whether the $\mathrm{pH}$-switch of the thiosquaramides mirrors the $\mathrm{p} K_{\mathrm{a}}$ values obtained through spectrophotometric titrations, the $\mathrm{Cl}^{-} / \mathrm{NO}_{3}{ }^{-}$experiments depicted in Fig. 2 were repeated at a range of $\mathrm{pHs}$ for receptors 1-3 (see $\mathrm{ESI} \dagger$ for details on the different pHs and buffers used). The exact position of the $\mathrm{pH}$ switch should correspond to the $\mathrm{p} K_{\mathrm{a}}$ value of the receptor under the conditions of the anion transport experiments ('apparent $\left.\mathrm{p} K_{\mathrm{a}}{ }^{\prime}\right) .{ }^{11}$ In order to calculate the apparent $\mathrm{p} K_{\mathrm{a}}$ of 3 , we plotted the normalised initial rate of chloride efflux versus $\mathrm{pH}$ and fitted the data to a sigmoidal function (Fig. 3). The values obtained using this method are summarised in Table 2 and largely agree with the $\mathrm{p} K_{\mathrm{a}}$ values determined above. These results clearly show that the chloride transport ability of 3 can be switched on at $\mathrm{pH}<7$, with the major switch occurring at $\mathrm{pH} \approx 7.0$. Fig. 3 also confirms that the chloride transport by the analogous (thio)squaramides $\mathbf{1}$ and $\mathbf{2}$ is also pH-dependent but in different

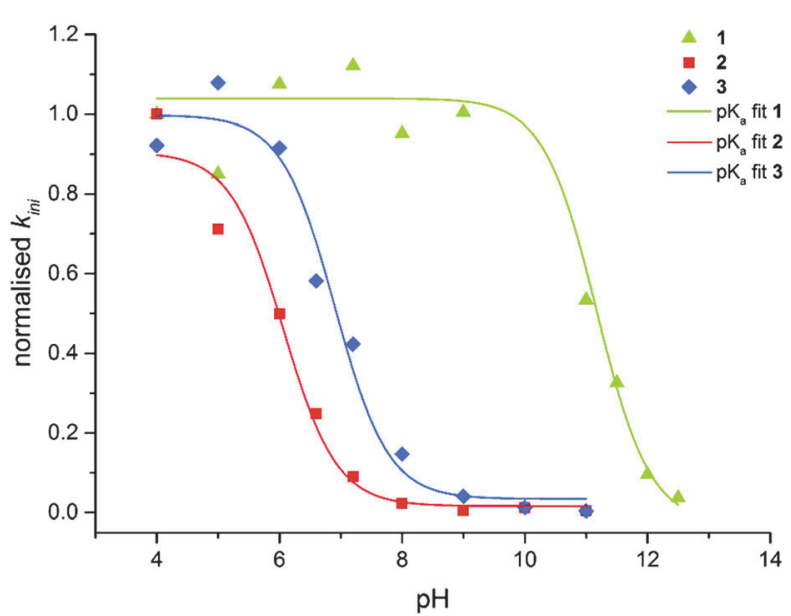

Fig. $3 \mathrm{pH}$ dependence of the chloride transport ability of oxo/thio/mixed squaramides 1-3 (1 mol\%). Chloride transport experiments were conducted as described in Fig. 2 but at various different pHs. The obtained data was fitted to an asymptotic function and the initial rate of chloride efflux $\left(k_{\text {ini }}\right)$ was calculated (see ESI $\dagger$ for details) and plotted as a function of $\mathrm{pH}$ after normalising by the maximum rate achievable at $\mathrm{pH}$ 4.0. Apparent $\mathrm{p} K_{\mathrm{a}}$ values could subsequently be estimated by fitting the obtained plot to the following sigmoidal function: $y=\max +\left((\min -\max ) /\left(1+10^{(\mathrm{pKa}-x)}\right)\right)$. 
$\mathrm{pH}$ windows. Clearly, squaramide 1 displays potent transmembrane anion transport activity across a large $\mathrm{pH}$ range ( $\mathrm{pH} 4-10)$, while thiosquaramide 2 is inactive above $\mathrm{pH} \approx 6$ and oxothiosquaramide 3 shows activity over an intermediate $\mathrm{pH}$ range.

In summary we have reported the first use of a mixed oxothiosquaramide as an efficient chloride receptor and $\mathrm{pH}$ switchable chloride transporter. Receptor 3 has similar anion binding properties to oxosquaramide 1 , forming strong complexes with chloride anions, as indicated by proton NMR titrations in DMSO- $d_{6}$. However, its $\mathrm{p} K_{\mathrm{a}}$ is closer to that of thiosquaramide 2 . Vesicle studies indicated that the trans-membrane anion transport ability of 3 is switched OFF at $\mathrm{pH}>7$ and switched $\mathrm{ON}$ at $\mathrm{pH}<7$. Importantly, the effect of the addition of one sulfur to the squaramide structure is large enough to cause the desired $\mathrm{pH}$ switch for transport while addition of a second sulfur moves the switch to lower $\mathrm{pH}$. This paper provides further evidence for the controllable and switchable anion transport nature of synthetic receptors containing the squaramide moiety. We are currently studying these and related systems for the development of future biologically active anion transporters.

We thank the EPSRC (EP/J009687/1) and the ARC (DP140100227) for funding. PAG thanks the Royal Society and the Wolfson Foundation for a Royal Society Wolfson Research Merit Award. PAG and KAJ thank the European Cooperation in Science and Technology (COST) action CM1005 "Supramolecular Chemistry in Water" for support.

\section{Notes and references}

1 J. T. Davis, O. Okunola and R. Quesada, Chem. Soc. Rev., 2010, 39, 3843-3862.

2 F. M. Ashcroft, Ion Channels and Disease, Academic Press, San Diego, 2000.

3 P. A. Gale, R. Pérez-Tomás and R. Quesada, Acc. Chem. Res., 2013, 46, 2801-2813.

4 N. Busschaert and P. A. Gale, Angew. Chem., Int. Ed., 2013, 52, 1374-1382.
5 S.-K. Ko, S. K. Kim, A. Share, V. M. Lynch, J. Park, W. Namkung, W. Van Rossom, N. Busschaert, P. A. Gale, J. L. Sessler and I. Shin, Nat. Chem., 2014, 6, 885-892.

6 J. T. Davis, in Topics in Heterocyclic Chemistry, ed. P. A. Gale and W. Dehaen, Springer, Berlin, Heidelberg, 2010, vol. 24, pp. 145-176.

7 L. E. Karagiannidis, C. J. E. Haynes, K. J. Holder, I. L. Kirby, S. J. Moore, N. J. Wells and P. A. Gale, Chem. Commun., 2014, 50, 12050-12053.

8 C. J. E. Haynes, N. Busschaert, I. L. Kirby, J. Herniman, M. E. Light, N. J. Wells, I. Marques, V. Felix and P. A. Gale, Org. Biomol. Chem., 2014, 12, 62-72.

9 N. Busschaert, I. L. Kirby, S. Young, S. J. Coles, P. N. Horton, M. E. Light and P. A. Gale, Angew. Chem., Int. Ed., 2012, 51, 4426-4430.

10 S. J. Edwards, H. Valkenier, N. Busschaert, P. A. Gale and A. P. Davis, Angew. Chem., Int. Ed., 2015, 54, 4592-4596.

11 N. Busschaert, R. B. P. Elmes, D. D. Czech, X. Wu, I. L. Kirby, E. M. Peck, K. D. Hendzel, S. K. Shaw, B. Chan, B. D. Smith, K. A. Jolliffe and P. A. Gale, Chem. Sci., 2014, 5, 3617-3626.

12 X. Ni, X. Li, Z. Wang and J.-P. Cheng, Org. Lett., 2014, 16, 1786-1789.

13 R. B. P. Elmes, P. Turner and K. A. Jolliffe, Org. Lett., 2013, 15, 5638-5641.

14 J. Bergman, B. Pettersson, V. Hasimbegovic and P. H. Svensson, J. Org. Chem., 2011, 76, 1546-1553.

15 M. B. Onaran, A. B. Comeau and C. T. Seto, J. Org. Chem., 2005, 70, 10792-10802.

16 P. Gans, A. Sabatini and A. Vacca, Talanta, 1996, 43, 1739-1753.

17 B. D. Smith and T. N. Lambert, Chem. Commun., 2003, 2261-2268.

18 A. V. Hill, Biochem. J., 1913, 7, 471-480.

19 E. Marchal, S. Rastogi, A. Thompson and J. T. Davis, Org. Biomol. Chem., 2014, 12, 7515-7522.

20 N. Busschaert, S. J. Bradberry, M. Wenzel, C. J. E. Haynes, J. R. Hiscock, I. L. Kirby, L. E. Karagiannidis, S. J. Moore, N. J. Wells, J. Herniman, G. J. Langley, P. N. Horton, M. E. Light, I. Marques, P. J. Costa, V. Félix, J. G. Frey and P. A. Gale, Chem. Sci., 2013, 4, 3036-3045.

21 H. Valkenier, C. J. E. Haynes, J. Herniman, P. A. Gale and A. P. Davis, Chem. Sci., 2014, 5, 1128-1134.

22 N. Busschaert, M. Wenzel, M. E. Light, P. Iglesias-Hernández, R. Pérez-Tomás and P. A. Gale, J. Am. Chem. Soc., 2011, 133, 14136-14148.

23 V. Saggiomo, S. Otto, I. Marques, V. Félix, T. Torroba and R. Quesada, Chem. Commun., 2012, 48, 5274-5276.

24 V. Sidorov, F. W. Kotch, G. Abdrakhmanova, R. Mizani, J. C. Fettinger and J. T. Davis, J. Am. Chem. Soc., 2002, 124, 2267-2278.

25 Y. Marcus, J. Chem. Soc., Faraday Trans., 1991, 87, 2995-2999. 